\title{
Ecophysiological characterization of two life forms, resting spores and resting cells, of a marine planktonic diatom, Chaetoceros pseudocurvisetus, formed under nutrient depletion
}

\author{
A. Kuwata ${ }^{1}$, T. Hama ${ }^{2}$, M. Takahashi ${ }^{1}$ \\ ${ }^{1}$ Botany Department, University of Tokyo, Hongo, Tokyo 113, Japan \\ ${ }^{2}$ Institute for Hydrospheric-Atmospheric Sciences, Nagoya University, Chikusa-ku, Nagoya 464-01, Japan
}

\begin{abstract}
Ecophysiological characteristics of 2 life forms, resting spores and resting cells, produced from vegetative cells of the marine diatom Chaetoceros pseudocurvisetus (Mangin) under nitrogen depletion were investigated. Carbon and silicon were concentrated in resting spores to a greater extent than nitrogen and chlorophyll a (chl a) although the levels of nitrogen and chl a were similar to those in vegetative cells. Resting cells were similar in appearance to vegetative cells but with weakly pigmented, shrunken and fragmented chloroplasts, and contained slightly more silicon, reduced nitrogen and chl a and similar amounts of carbon in comparison with the vegetative cells. Respiratory and photosynthetic activity was depressed in both resting spores and resting cells. Net photosynthesis was slightly positive in resting spores and slightly negative in resting cells. Both resting spores and resting cells accumulated neutral lipids mainly composed of myristic $\left(C_{14: 0}\right)$, palmitic $\left(C_{16: 0}\right)$ and palmitoleic $\left(\mathrm{C}_{16: 1}\right)$ acids as a stored energy source with increased unsaturation of fatty acids. Resting spores also stored large amounts of glucose in reserved polysaccharides. These characteristics indicate that each life form represents a different degree of the adaptive resting stage for survival under nutrient depletion.
\end{abstract}

KEY WORDS: Chemical composition - Diatom $\cdot$ Metabolic activity $\cdot$ Nutrient deficiency $\cdot$ Resting cell Resting spore - Survival stage

\section{INTRODUCTION}

Under fluctuating natural environments with various temporal and spatial scales, each planktonic algal population is expected to be exposed to both favorable and unfavorable conditions for growth and reproduction. Since planktonic algae are not mobile enough to select favorable conditions and to avoid unfavorable conditions by themselves, their lives will be strongly affected by environmental fluctuations. For each planktonic algal species to maintain population levels during such environmental fluctuations, it is essential to survive under unfavorable conditions as well as to grow actively under favorable conditions.

Nutrient depletion is a harsh condition to which planktonic algae are occasionally or even frequently exposed in the sea. For the successful establishment of many planktonic algae under fluctuating nutrient conditions in the marine environment, some mechanisms may exist. In fact, several species of marine planktonic diatoms have been found to form resting spores associated with nutrient depletion (Drebes 1966, Davis et al. 1980, Garrison 1981, Ishizaka et al. 1987, Kuwata \& Takahashi 1990). Furthermore, Kuwata \& Takahashi (1990) have revealed that, in a planktonic diatom Chaetoceros pseudocurvisetus Mangin population, resting spore formation induced by nitrogen depletion requires a large amount of silicon, and that a part of the algal population which fails to form resting spores remains vegetative looking with weakly pigmented, shrunken and fragmented chloroplasts, as observed by Holmes (1966) under insufficient supply of silicic acid.

Chaetoceros pseudocurvisetus was originally described as a tropical or subtropical species (Cupp 
1943). This species has recently been observed frequently in warm waters in the Japanese coastal region and its bloom has been reported to be common in some bays from autumn to spring (Takano 1990). It has also been found in locally upwelling water frequently occurring in the Izu Islands, Japan, where the nutrient environment changed greatly from eutrophy to oligotrophy within several days (Takahashi et al. 1986, Kuwata \& Takahashi 1990).

Considering the actual concurrence of both resting spores and such vegetative-looking cells of this algal population in oligotrophic water, each life form might exhibit resting stages capable of surviving under nutrient depletion, which play an important role for survival in natural water. To verify this possibility, ecophysiological characterization of both resting spores and vegetative-looking cells is required. However, there have been only a few studies evaluating some characteristics of resting spores and vegetative cells of diatom species (French \& Hargraves 1980, Doucette \& Fryxell 1983).

In this study, resting spores and vegetative-looking resting cells of Chaetoceros pseudocurvisetus are compared to vegetative cells with regard to survival under nutrient deficiency. Since reduction of metabolic activity and storage of energy were considered to be essential for the survival of many organisms (Sussman \& Douhit 1973), particular attention was paid to changes in metabolic activity and chemical composition during the transition from vegetative cells to resting spores or vegetative-looking cells formed under nutrient depletion.

\section{MATERIALS AND METHODS}

Preparation of $\mathbf{3}$ life forms by laboratory culture. Isolation of the unialgal strain of Chaetoceros pseudocurvisetus and maintenance of culture were described previously (Kuwata \& Takahashi 1990).

Algal samples were prepared in batch culture using $8 \mathrm{l}$ polycarbonate bottles at $24 \pm 1.5^{\circ} \mathrm{C}$ under a $14 \mathrm{~h}$ light: $10 \mathrm{~h}$ dark lighting cycle (ca $600 \mu \mathrm{mol} \mathrm{m} \mathrm{m}^{-2} \mathrm{~s}^{-1}$ provided by daylight-type fluorescent tubes). According to the previous study (Kuwata \& Takahashi 1990), a Chaetoceros pseudocurvisetus population produces almost solely resting spores under depletion of nitrogenous nutrients with enough silicic acid (required $\mathrm{Si} / \mathrm{N}$ molar ratio $>9.3$ ) or produces only vegetativelooking resting cells under concomitant deficiency of silicic acid and nitrogenous nutrients (required $\mathrm{Si} / \mathrm{N}$ molar ratio $<3.1$ ). To obtain the 2 different types of life form separately under nitrogen deficiency, the cells were grown in modified $\mathrm{f} / 2$ medium (Guillard \& Ryther 1962) with $10 \mu \mathrm{M}$ nitrate and $140 \mu \mathrm{M}$ silicic acid for resting spores and $10 \mu \mathrm{M}$ nitrate and $20 \mu \mathrm{M}$ silicic acid for vegetative-looking cells. Samples of vegetative cells were cultured in a modified $f / 2$ medium containing nitrate $(20 \mu \mathrm{M})$ and silicic acid $(160 \mu \mathrm{M})$.

Culture media in polycarbonate bottles were autoclaved at $120^{\circ} \mathrm{C}$ under $2 \mathrm{~atm}$, and cooled at least for $24 \mathrm{~h}$ at room temperature after autoclaving and before inoculating cells at the logarithmic growth phase at an initial concentration of ca 30 cells $\mathrm{ml}^{-1}$. All the cultures were preincubated for $1 \mathrm{~d}$.

Samples for cell counting were all fixed with glutaraldehyde $(2.5 \% \mathrm{v} / \mathrm{v})$ and settled in chambers before counting with an inverted microscope (Utermöhl 1958). Cell volume was estimated using the equation of Miyai et al. (1988) from cell length and width determined with 200 preserved cells for each sample, assuming an elliptical cylindrical shape for vegetative and vegetative-looking cells and an ellipsoidal shape for resting spores. Each sample for nutrient analysis was filtered through a cellulose acetate filter (Advantec, DISMIC-25cs) and nitrate and silicic acid determined colorimetrically according to Strickland \& Parsons (1972). Samples for chemical analyses of resting spores were collected from culture on Day 8 and those of vegetative-looking cells on Day 9 after inoculation into a fresh medium. Vegetative cells were harvested during the logarithmic growth phase on Day 4 .

Metabolic rate measurements. Rates of photosynthesis and dark respiration were determined by oxygen changes using the dark and light bottle method with the Winkler titration. Vegetative-looking cells and resting spores were prepared in the modified $\mathrm{f} / 2$ media as mentioned above. Vegetative cells were prepared in the medium containing initial concentrations of $50 \mu \mathrm{M}$ nitrate and $150 \mu \mathrm{M}$ silicic acid. To avoid overestimation of respiratory activity due to contamination by bacteria, preculture for resting cells and resting spores was rendered axenic by treatments with penicillin and streptomycin (Hoshaw \& Rosowski 1973). Vegetative cells were harvested during the logarithmic growth phase. Resting cells were taken 2 d after entering the stationary phase. Resting spores were obtained 4 to $6 \mathrm{~d}$ after their formation. Five bottles each were prepared for light, dark and control treatments. Two $100 \mathrm{ml}$ bottles were treated as light bottles, and the changes in chl a and cell concentrations were determined during the incubation. All the light and dark bottles were incubated for $3 \mathrm{~h}$ for vegetative cells, and for $14 \mathrm{~h}$ for resting cells and resting spores at $25^{\circ} \mathrm{C}$. Light bottles were incubated under saturated light intensity ( $>200 \mu \mathrm{mol} \mathrm{m} \mathrm{m}^{-2} \mathrm{~s}^{-1}$ ) for photosynthesis provided by daylight-type fluorescent tubes.

Chemical analyses. Cellular organic carbon and nitrogen contents were determined with a $\mathrm{CN}$ analyzer (Sumigraph NC80) by filtering algal cell samples 
on a Whatman GF/C glass fiber filter precombusted at $400^{\circ} \mathrm{C}$. Cellular silicon content was determined using the method of Paasche (1980) by filtering algal samples on a $0.6 \mu \mathrm{m}$ pore size polycarbonate filter (Isopore, Milipore) Cellular chl a content was determined by fluorometry (Strickland \& Parsons 1972) after extraction with $\mathrm{N}, \mathrm{N}$-dimethylformamide from sample retained on Whatman GF/C glass fiber filters (Suzuki \& Ishimaru 1990).

Samples for fatty acid and carbohydrate analyses were filtered on precombusted Whatman GF/C glass fiber filters. Each filter was put into a stoppered $10 \mathrm{ml}$ test tube, $3 \mathrm{ml}$ of chloroform and $1.5 \mathrm{ml}$ of methanol were added, and it was then sonicated for $15 \mathrm{~min}$. The residue was separated from the extract by centrifugation. This treatment was repeated 3 times. Distilled water $(4.5 \mathrm{ml})$ was added to the extract and then mixed vigorously. After the extract was separated into methanol $\cdot \mathrm{H}_{2} \mathrm{O}$ and chloroform layers, the former (which contained low molecular weight compounds, around 200 dalton; Hama \& Handa 1987) was removed by a pasteur pipette. The chloroform fraction consisted of lipid materials. After removal of chloroform under a supply of nitrogen, fatty acids were saponified using a benzene $/ 0.5 \mathrm{~N} \mathrm{KOH} /$ methanol mixture, and then methylated using $\mathrm{BF}_{3}$-methanol at $100^{\circ} \mathrm{C}$ for $3 \mathrm{~h}$. Fatty acid methyl esters were extracted with $\mathrm{n}$-hexane and analyzed by gas chromatography (Shimadzu GC 14A, equipped with a flame ionization detector, and a Shimadzu C-R6A data system). A fused silica capillary column (HR-SS-10, $25 \mathrm{~m} \times 0.25 \mathrm{~mm}$ i.d.; Shinwa Chemical Industries) was used with $\mathrm{N}_{2}$ as carrier gas. Oven temperature was programmed to change from 120 to $230^{\circ} \mathrm{C}$ at $3^{\circ} \mathrm{C} \mathrm{min}^{-1}$ and held isothermally for $15 \mathrm{~min}$. $\mathrm{C}_{21}$ o was used as internal standard. Neutral lipids (free fatty acids and triglycerides), polar lipids, hydrocarbons plus sterolesters and diglycerides were separated by thin layer chromatography (TLC: Merck silica gel 60) by using n-hexane:ethyl ether:acetic acid $(70: 30: 1, v / v)$ as developing solvent. Fatty acids in each lipid class were determined as mentioned above.

The residue from chloroform and methanol extraction was suspended in $20 \mathrm{ml}$ of distilled deionized water and extracted at $100^{\circ} \mathrm{C}$ for $45 \mathrm{~min}$. The suspension was filtered through a glass fiber filter and then washed with $5 \mathrm{ml}$ of distilled deionized water. This hot water extract, consisting mainly of reserved polysaccharides (Hama \& Handa 1992), was treated with $1 \mathrm{~N}$ $\mathrm{H}_{2} \mathrm{SO}_{4}$ at $100^{\circ} \mathrm{C}$ for $5 \mathrm{~h}$ to hydrolyze oligo- and polysaccharides to monosaccharides. Monosaccharides of the methanol-soluble, hot-water-soluble and residual fractions were converted to their acetyl derivatives (Handa \& Yanagi 1969). Analyses of the acetyl derivatives of monosaccharides were performed by a gas chromatograph (Shimadzu GC 14A.). An open tubular column, the wall coated with fused silica (OV-1701, $25 \mathrm{~m} \times 0.25 \mathrm{~mm}$ i.d.; GL Science), was used with $\mathrm{N}_{2}$ as carrier gas. Oven temperature was programmed to change from 150 to $280^{\circ} \mathrm{C}$ at $4{ }^{\circ} \mathrm{C} \mathrm{min} \mathrm{min}^{-1}$ and held isothermally for $15 \mathrm{~min}$. Fatty acids and monosaccharides were identified by the retention time of authentic specimens and gas chromatograph-mass spectrometry (JEOL DX-302).

\section{RESULTS}

\section{Formation of resting spores and resting cells}

In the resting-spore formation culture, vegetative cells of Chaetoceros pseudocurvisetus (Fig. 1A), which dominated during the first $3 \mathrm{~d}$ in the population, increased exponentially at a rate of $1.6 \mathrm{~d}^{-1}$ and reached a maximum of ca 20000 cells $\mathrm{ml}^{-1}$ after $3 \mathrm{~d}$ (Fig, 2), Resting spores (Fig. 1B) first appeared on Day 3 and increased rapidly over the next $2 \mathrm{~d}$. Final resting spore yield was $96 \%$ of the maximum vegetative cell numbers. The rest were vegetative-looking cells which had weakly pigmented, shrunken and fragmented chloroplasts (Fig. 1C). Nitrate concentration decreased rapidly during the logarithmic growth phase to a minimum of $0.1 \mu \mathrm{M}$ after Day 3. Silicic acid also decreased rapidly during the periods of both logarithmic growth and resting spore formation. The lowest concentration of silicic acid $(27 \mu \mathrm{M})$ was encountered on Day 5 as resting spore formation nearly terminated. The molar ratio of silicic acid to nitrate consumed by the population in this culture was 12 .

In the culture for vegetative-looking cell formation, logarithmic growth lasted for $3 \mathrm{~d}$ from the beginning of the experiment and a constant population density of ca 20000 cells $\mathrm{ml}^{-1}$ was maintained after Day 3 (Fig. 3). Entering the stationary phase on Day 3, nearly $100 \%$ of normal vegetative cells turned into the vegetativelooking cells with weakly pigmented, shrunken and fragmented chloroplasts. Final yield of resting spores in this culture was less than $0.1 \%$. Nitrate concentration decreased rapidly accompanying the logarithmic growth and reached $0.6 \mu \mathrm{M}$ on the Day 2. The concentration then slowly decreased to a minimum of $0.1 \mu \mathrm{M}$ and remained at this low level. Silicic acid concentration decreased rapidly until Day 3 and reached a minimum of $0.1 \mu \mathrm{M}$. The molar ratio of silicic acid to nitrate consumed by the population in this culture was 2.3 .

The vegetative-looking cells with weakly pigmented, shrunken and fragmented chloroplasts (hereafter referred to as 'resting cells') emerged in both cultured populations. The term 'resting cell' was originally proposed by Lund (1954) for some freshwater diatom cells resting due to lack of radiation at low temperature. 

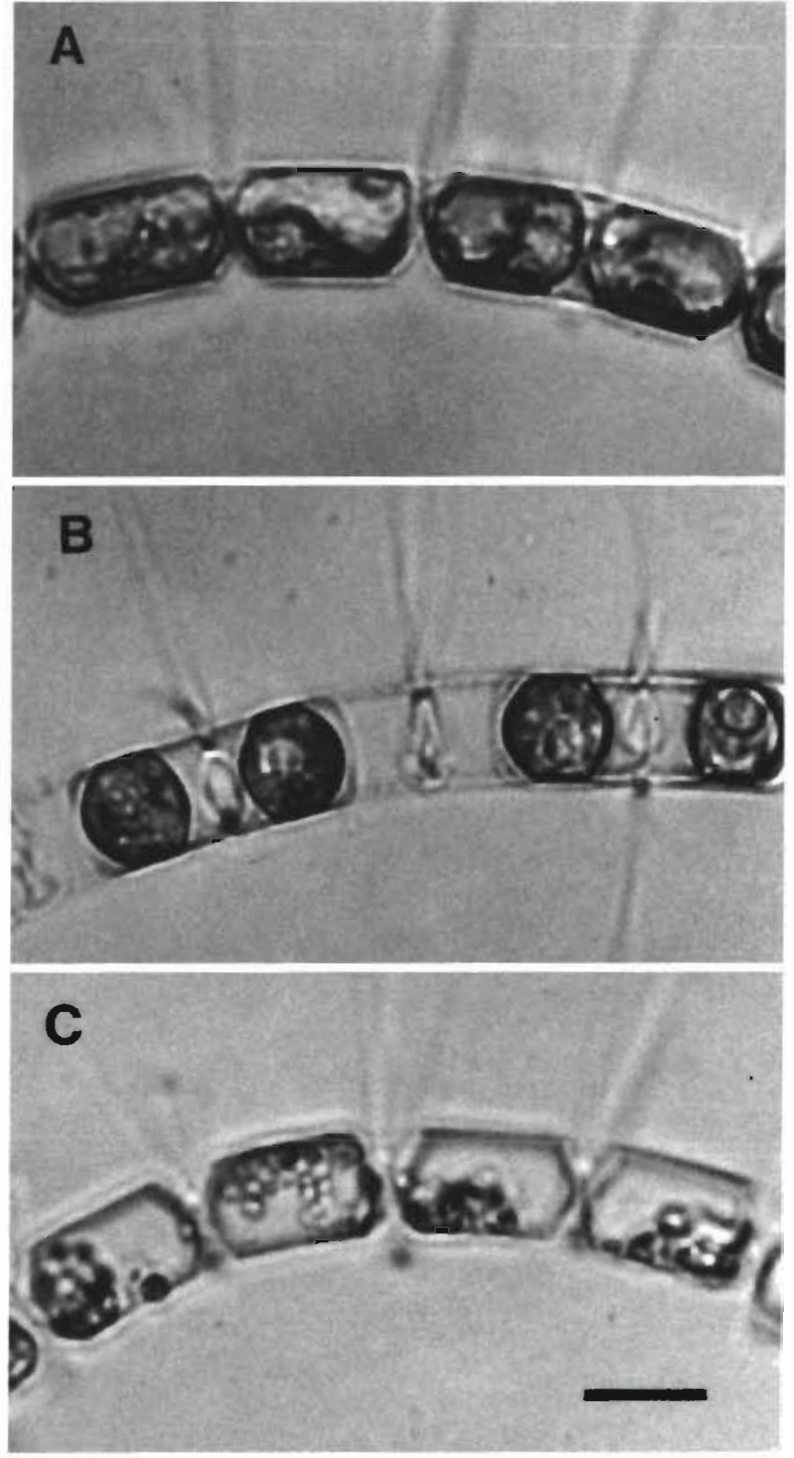

Fig. 1. Chaetoceros pseudocurvisetus. Light micrographs of (A) vegetative cells; (B) resting spores; (C) resting cells. Scale bar $=10 \mu \mathrm{m}$

Although the vegetative-looking cells in the present study were formed due to an insufficient supply of nitrogenous and silicious nutrients, they all showed no positive growth and had the above-mentioned characteristic morphologies which resemble the reported characteristics of a 'resting cell'.

\section{Photosynthesis and dark respiration}

Photosynthetic and dark respiratory rates were determined for each life form of resting spores, resting cells and vegetative cells in the logarithmic growth phase (Table 1). Gross photosynthetic rates per cell of

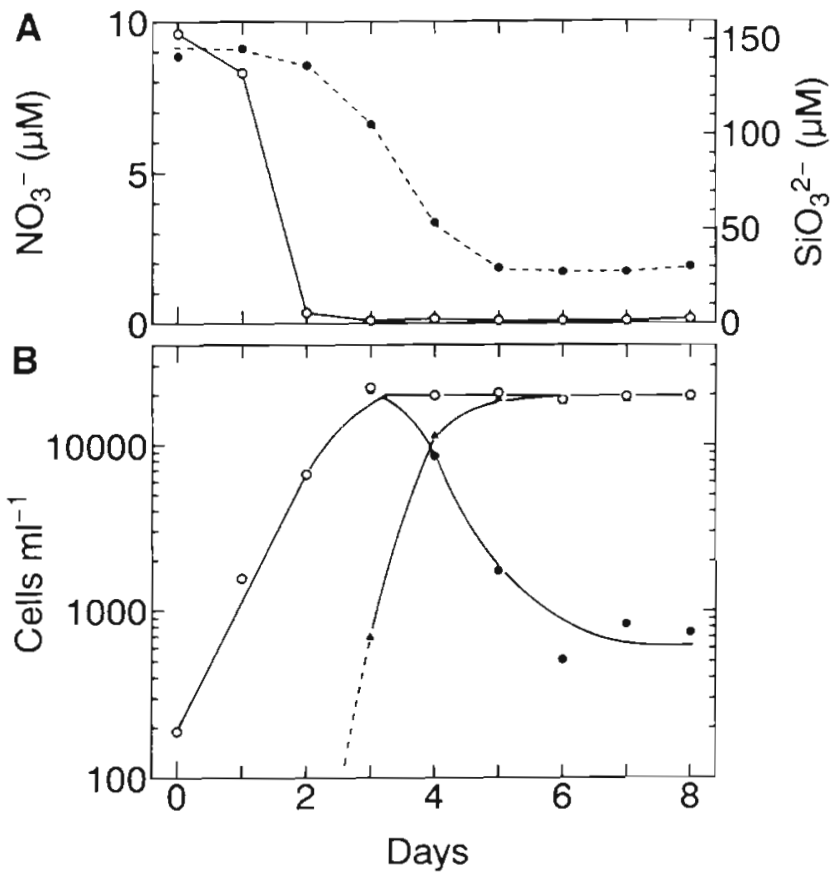

Fig. 2. Chaetoceros pseudocurvisetus. Changes in (A) concentrations of nitrate $(0)$ and silicic acid $(\bullet)$ in the resting spore formation culture, and (B) densities of resting cells $(\bullet)$, resting spores ( 4 ) and whole population ( 0 )
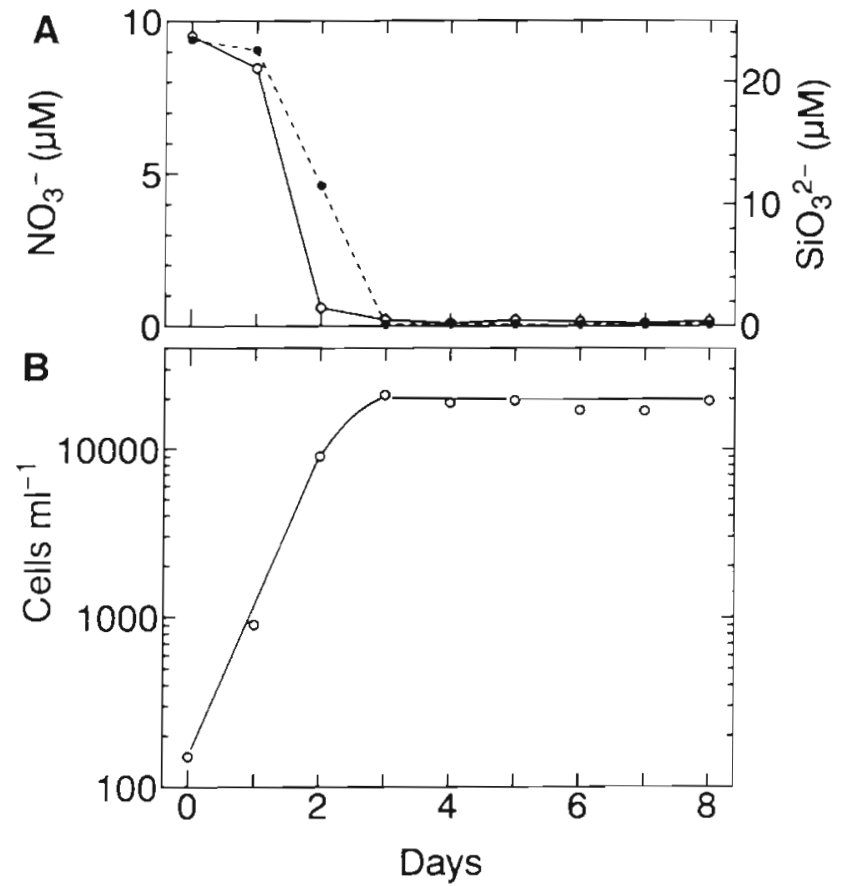

Fig. 3. Chaetoceros pseudocurvisetus. Changes in (A) concentrations of nitrate (0) and silicic acid $(\bullet)$ and $(B)$ density of the whole population $(0)$ in the resting cell formation culture 
Table 1. Chaetoceros pseudocurvisetus. Photosynthetic and respiratory activity of vegetative and resting cells and resting spores

\begin{tabular}{|lccc|}
\cline { 2 - 3 } & $\begin{array}{c}\text { Vegetative } \\
\text { cells }\end{array}$ & $\begin{array}{c}\text { Resting } \\
\text { cells }\end{array}$ & $\begin{array}{c}\text { Resting } \\
\text { spores }\end{array}$ \\
\hline $\begin{array}{l}\text { Gross photosynthesis } \\
\left(\mathrm{pg} \mathrm{O}_{2} \mathrm{cell}^{-1} \mathrm{~h}^{-1}\right)\end{array}$ & 41.5 & 1.3 & 1.4 \\
$\left(\mathrm{mg} \mathrm{O}_{2} \mathrm{mg} \mathrm{chl} \mathrm{a}^{-1} \mathrm{~h}^{-1}\right)$ & 32.1 & 5.5 & 2.5 \\
$\begin{array}{l}\text { Dark respiration } \\
\left(\mathrm{pg} \mathrm{O} \mathrm{O}_{2} \text { cell }^{-1} \mathrm{~h}^{-1}\right)\end{array}$ & 4.8 & 1.5 & 0.5 \\
$\left.\begin{array}{l}\text { Diel net photosynthesis } \\
\left(\mathrm{pg} \mathrm{O} \mathrm{O}_{2} \text { cell }\right.\end{array} \mathrm{d}^{-1}\right)$ & 470 & -19 & 7 \\
\hline
\end{tabular}

resting spores and resting cells were almost the same and decreased to less than a thirtieth of that of vegetative cells. The decrease in photosynthetic rates normalized to chl a was a little less pronounced compared with per cell bases; 8 and $17 \%$ in the resting spores and the resting cells relative to the vegetative cells, respectively. Dark respiratory rates also decreased significantly in resting spores and resting cells, reaching about 10 and $30 \%$ respectively of that of vegetative cells.

Diel net photosynthetic rate of each life form was calculated using the obtained gross photosynthetic and dark respiratory rates under the $14 \mathrm{~h}: 10 \mathrm{~h}$ light:dark cycle. Resting spores showed a positive but low net photosynthetic rate, $1.6 \%$ of that of vegetative cells, while that of resting cells was negative with an absolute value of $4 \%$ of that of vegetative cells.

\section{Major chemical components}

Major chemical components of the 3 life forms were determined (Table 2). Resting spores contained 1.5 times more organic carbon but half as much organic nitrogen as vegetative cells. Resting cells contained almost the same amount of organic carbon and half the amount of organic nitrogen of vegetative cells. Then, the $C: N$ ratio (by atoms) of resting spores was 4 times higher than that of vegetative cells, and 2 times higher than that of resting cells. Cellular chl a contents of resting spores and resting cells were far smaller than those of vegetative cells. Consequently, C:chl a ratios of both resting spores and resting cells became very much higher than those of vegetative cells.

The temporal changes of silicic acid consumption from logarithmic vegetative growth to the formation of resting spores or resting cells (Figs. $2 \& 3$ ) suggested possible differences of cellular silicon contents among different types of cells. Resting spores contained 3
Table 2. Chaetoceros pseudocurvisetus. Chemical composition of vegetative and resting cells and resting spores. Standard errors in parentheses $(n=3)$

\begin{tabular}{|c|c|c|c|}
\hline & $\begin{array}{c}\text { Vegetative } \\
\text { cells }\end{array}$ & $\begin{array}{l}\text { Resting } \\
\text { cells }\end{array}$ & $\begin{array}{c}\text { Resting } \\
\text { spores }\end{array}$ \\
\hline $\begin{array}{l}\mathrm{C} \\
\left(\mathrm{pmol} \mathrm{cell}^{-1}\right)\end{array}$ & $\begin{array}{c}5.86 \\
(0.10)\end{array}$ & $\begin{array}{l}5.90 \\
(0.64)\end{array}$ & $\begin{array}{c}9.96 \\
(0.10)\end{array}$ \\
\hline $\begin{array}{l}\mathrm{N} \\
\left(\text { pmol cell }{ }^{-1}\right)\end{array}$ & $\begin{array}{c}1.07 \\
(0.028)\end{array}$ & $\begin{array}{l}0.56 \\
(0.024)\end{array}$ & $\begin{array}{l}0.48 \\
(0.005)\end{array}$ \\
\hline $\begin{array}{l}\text { Si } \\
\left(\mathrm{pmol} \mathrm{cell}^{-1}\right)\end{array}$ & $\begin{array}{c}1.25 \\
(0.02)\end{array}$ & $\begin{array}{c}1.59 \\
(0.02)\end{array}$ & $\begin{array}{c}4.67 \\
(0.04)\end{array}$ \\
\hline $\begin{array}{l}\text { Chl a } \\
\left(\mathrm{pg} \mathrm{cell}{ }^{-1}\right)\end{array}$ & $\begin{array}{c}1.06 \\
(0.00)\end{array}$ & $\begin{array}{c}0.268 \\
(0.017)\end{array}$ & $\begin{array}{c}0.175 \\
(0.003)\end{array}$ \\
\hline $\mathrm{C}\left(\mathrm{fmol} \mu \mathrm{m}^{-3}\right)$ & 3.80 & 3.87 & 39.4 \\
\hline$N\left(\mathrm{fmol} \mu \mathrm{m}^{-3}\right.$ ) & 0.69 & 0.37 & 1.88 \\
\hline $\mathrm{Si}\left(\mathrm{fmol} \mu \mathrm{m}^{-3}\right)$ & 0.81 & 1.04 & 18.5 \\
\hline $\mathrm{Chl} a\left(\mathrm{fg} \mu \mathrm{m}^{-3}\right)$ & 0.689 & 0.176 & 0.693 \\
\hline $\begin{array}{l}\text { Cell volume } \\
\left(\mu \mathrm{m}^{3}\right)\end{array}$ & $\begin{array}{l}1540 \\
(80)\end{array}$ & $\begin{array}{l}1520 \\
(50)\end{array}$ & $\begin{array}{l}253 \\
(6)\end{array}$ \\
\hline $\mathrm{C}: \mathrm{N}(\mathrm{mol} / \mathrm{mol})$ & 5.50 & 10.5 & 21.0 \\
\hline $\mathrm{Si}: \mathrm{N}(\mathrm{mol} / \mathrm{mol})$ & 1.18 & 2.81 & 9.82 \\
\hline C:chl a $(g / g)$ & 66.2 & 264 & 682 \\
\hline
\end{tabular}

times more silicon than vegetative cells, while cellular silicon contents of resting cells were slightly more than those of vegetative cells. The Si: $\mathrm{N}$ ratio (by atoms) of resting spores was 8 times higher than that of vegetative cells, and that of resting cells was twice as high as that of vegetative cells.

Cellular volume of resting spores decreased markedly, and was a sixth of the volume of vegetative cells, while those of resting and vegetative cells were about the same. The chemical composition of resting spores mentioned above then appeared to have the highest values of carbon, nitrogen and silica when normalized with cellular volume. Chl a content by cell volume of vegetative cells and resting spores were comparable and more than that of resting cells.

These results indicate that resting spores accumulated a large amount of carbon and silicon, but less nitrogen and chl a which were present in concentrations similar to those in vegetative cells. Compared with vegetative cells, a slight accumulation of silicon but a great reduction of nitrogen and chl a occurred in resting cells, with no major changes in the total carbon contents.

These changes in chemical composition during the life form changes of vegetative cells into resting spores or resting cells under nitrogen depletion are expected to be accompanied by possible altered partitioning and/or redistribution of newly and/or previously accu- 


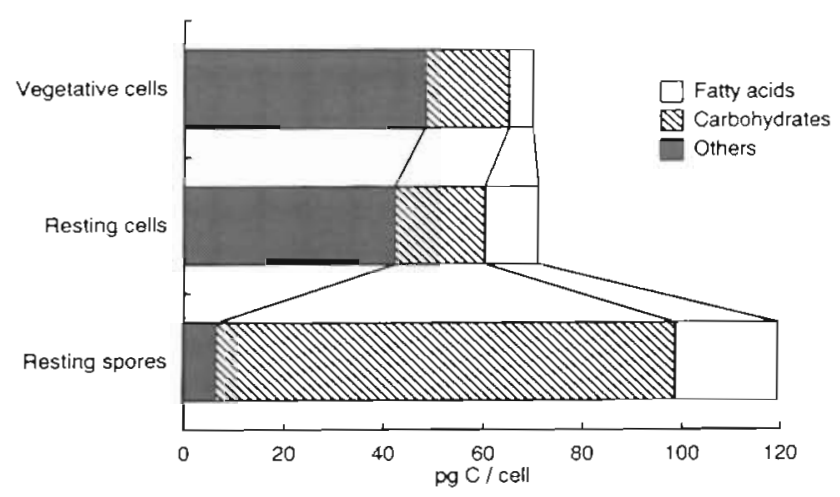

Fig. 4. Chaetoceros pseudocurvisetus. Contents of organic carbon in different components of vegetative and resting cells and resting spores

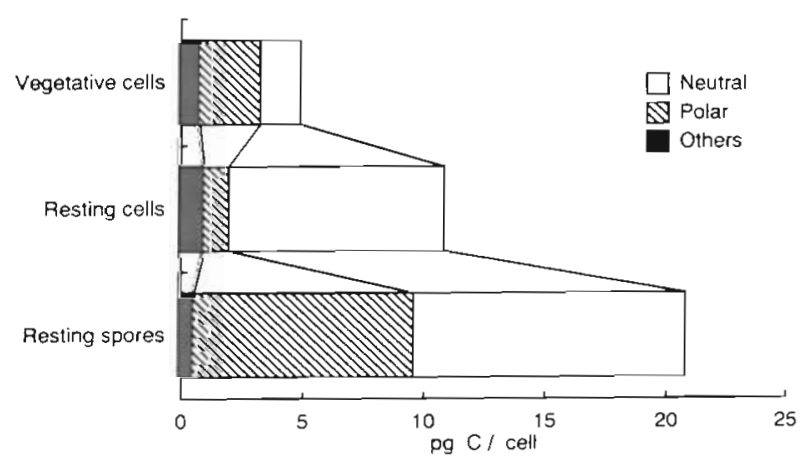

Fig. 5. Chaetoceros pseudocurvisetus. Fatty acid contents of neutral and polar lipids and other lipid classes of vegetative and resting cells and resting spores

mulated carbon. Organic carbon compounds of the above-mentioned 3 life forms were paid particular attention, and were further analyzed in 3 major forms (e.g. fatty acids in lipids, and carbohydrates; Fig. 4). The fatty acid content of resting spores was more than 4 times that of vegetative cells, and the carbohydrate content was more than 5 times that of vegetative cells. Compared with vegetative cells, resting cells contained more than 2 times as much fatty acids, while the carbohydrate content did not differ significantly between the 2 types of cells. Fatty acids in lipids of resting spores and resting cells represented more than $15 \%$ of total carbon content, while those of vegetative cells were less than $7 \%$. It is noteworthy that the carbohydrates of resting spores represented more than $75 \%$ of total carbon content, while those of vegetative and resting cells represented less than $30 \%$. Both vegetative and resting cells consisted mainly of other compounds, which reached about or more than $60 \%$ of total carbon, while those of resting spores reached only
$5 \%$. These other carbon compounds included mainly proteins, nucleic acids, and non-fatty acids in lipids.

\section{Lipid components}

Lipids were further separated into polar, neutral and other forms (hydrocarbon plus sterolester and diglyceride), and the results showed significant differences among the 3 life forms, particularly in polar and neutral lipids by carbon base of fatty acids (Fig. 5). Both neutral and polar lipids were major components constituting 84 to $97 \%$ of total lipids in all 3 life forms. Resting spores contained more than 6 times as much neutral lipids and more than 3 times as much polar lipids compared to vegetative cells. Resting cells cantained more than 5 times as much neutral lipids and less than half as much polar lipids compared to vegetative cells. Neutral lipids occupied more than $80 \%$ of total lipids for resting cells and more than $50 \%$ for resting spores, but only $35 \%$ for vegetative cells. Polar lipids of resting spores and vegetative cells reached more than $40 \%$ of total lipids, while that of resting cells was only $9 \%$.

Fatty acids of total lipids were analyzed and found to be comprised mainly of 3 components, myristic $\left(\mathrm{C}_{14: 0}\right)$, palmitic $\left(\mathrm{C}_{16: 0}\right)$ and palmitoleic $\left(\mathrm{C}_{16: 1}\right)$ acids, in all 3 life forms (Table 3). These fatty acids occupied about or more than $70 \%$ of total fatty acids in the 3 life forms. However, cellular contents of these 3 fatty acids differed significantly. Resting spores contained over 5 times as much $C_{14.0}, 2$ times as much $C_{16: 0}$ and 14 times as much $\mathrm{C}_{16: 1}$ fatty acids compared to vegetative cells.

Table 3. Chaetoceros pseudocurvisetus. Major fatty acid composition ( $\mathrm{pg} \mathrm{C} \mathrm{Cell}^{-1}$ ) of vegetative and resting cells and resting spores. Numbers in parentheses are percentages of total fatty acids. +: trace

\begin{tabular}{|c|c|c|c|}
\hline $\begin{array}{l}\text { Fatty } \\
\text { acid }\end{array}$ & $\begin{array}{l}\text { Vegetative } \\
\text { cells }\end{array}$ & $\begin{array}{l}\text { Resting } \\
\text { cells }\end{array}$ & $\begin{array}{l}\text { Resting } \\
\text { spores }\end{array}$ \\
\hline $\mathrm{C}_{140}$ & $0.696(14.2)$ & $2.04(19.0)$ & $3.79(18.2)$ \\
\hline $\mathrm{C}_{16 \overline{0}}$ & $2.13 \quad(43.5)$ & $3.31(30.7)$ & $4.32(20.8)$ \\
\hline$C_{16.1}(n-7)$ & $0.704(14.4)$ & $3.76(35.0)$ & $10.3 \quad(49.4)$ \\
\hline $\mathrm{C}_{18: 0}$ & $0.319 \quad(6.5)$ & $0.250(2.3)$ & $0.345(1.7)$ \\
\hline$C_{18: 1}(n-9)$ & $0.178 \quad(3.6)$ & $0.173(1.3)$ & $0.811(3.9)$ \\
\hline $\mathrm{C}_{18.2}$ & + & $0.004(0.04)$ & $0.153(0.7)$ \\
\hline $\mathrm{C}_{18: 4}$ & + & $0.130(1.2)$ & + \\
\hline$C_{18.5}$ & $0.064 \quad(1.3)$ & $0.004 \quad(0.04)$ & + \\
\hline $\mathrm{C}_{20: 5}$ & $0.095 \quad(1.9)$ & $0.075(0.7)$ & $0.120(0.6)$ \\
\hline $\mathrm{C}_{20.6}$ & $0.113 \quad(2.3)$ & $0.063(0.6)$ & + \\
\hline \multicolumn{4}{|c|}{ Unsaturation ratios: } \\
\hline$C_{16 \text { unsar }}: C_{160}$ & 0.379 & 1.17 & 2.39 \\
\hline $\mathrm{C}_{18 \text { ursat }}: \mathrm{C}_{18: 0}$ & 1.55 & 2.77 & 3.11 \\
\hline $\begin{array}{l}\text { Total unsat.: } \\
\text { total sat. }\end{array}$ & 0.998 & 1.50 & 2.59 \\
\hline
\end{tabular}


Table 4. Chaetoceros pseudocurvisetus. Major fatty acid composition (pg C cell ${ }^{-1}$ ) of neutral and polar lipids of vegetative and resting cells and resting spores. Numbers in parentheses are percentages of total fatty acids of each lipid class. NL: neutral lipids; PL: polar lipids; +: trace

\begin{tabular}{|c|c|c|c|c|c|c|}
\hline \multirow[t]{2}{*}{ Fatty acid } & \multicolumn{2}{|c|}{ Vegetative cells } & \multicolumn{2}{|c|}{ Resting cells } & \multicolumn{2}{|c|}{ Resting spores } \\
\hline & $\mathrm{NL}$ & PL & NL & PL & NL & PL \\
\hline$C_{14 \cdot 0}$ & $0.34(20.7)$ & $0.14 \quad(5.7)$ & $1.59(18.0)$ & $0.09(9.5)$ & $2.17(19.4)$ & $2.00(22.2)$ \\
\hline$C_{16.0}$ & $0.59(35.5)$ & $0.78(31.4)$ & $2.81(31.7)$ & $0.18(17.7)$ & $2.33(20.8)$ & $2.23(24.7)$ \\
\hline$C_{16 \cdot 1}(n-7)$ & $0.30(18.2)$ & $0.18 \quad(7.4)$ & $3.26(36.8)$ & $0.10(10.0)$ & $5.51(49.2)$ & $3.55(39.3)$ \\
\hline$C_{18 \cdot 0}$ & $0.17(10.0)$ & $0.63(25.4)$ & $0.58 \quad(6.5)$ & $0.13(13.6)$ & $0.26 \quad(2.3)$ & $0.28 \quad(3.1)$ \\
\hline$C_{18 \cdot 1}(n-9)$ & $0.08 \quad(5.1)$ & $0.21 \quad(8.7)$ & $0.17 \quad(1.9)$ & $0.01 \quad(1.4)$ & $0.54 \quad(4.8)$ & $0.33 \quad(3.6)$ \\
\hline $\mathrm{C}_{182}$ & $0.00 \quad(0.2)$ & $0.01 \quad(0.6)$ & $0.02 \quad(0.2)$ & $0.00 \quad(0.4)$ & $0.08 \quad(0.7)$ & $0.06 \quad(0.7)$ \\
\hline $\mathrm{C}_{20: 5}$ & $0.05 \quad(2.8)$ & $0.09 \quad(3.6)$ & $0.06 \quad(0.7)$ & $0.12(11.8)$ & $0.04 \quad(0.4)$ & $0.05 \quad(0.5)$ \\
\hline $\mathrm{C}_{20: 6}$ & + & + & $0.01 \quad(0.1)$ & $0.14(14.9)$ & $0.08 \quad(0.7)$ & $0.01 \quad(0.1)$ \\
\hline
\end{tabular}

Resting cells contained more than 3 times as much $\mathrm{C}_{14: 0}, 1.5$ times as much $\mathrm{C}_{16: 0}$ and 5 times as much $\mathrm{C}_{16: 1}$ fatty acids compared to vegetative cells. Each life form contained a small amount of $\mathrm{C}_{18}$ fatty acids and polyunsaturated $\mathrm{C}_{20}$ fatty acids. The unsaturation ratio of fatty acids also differed significantly among the 3 life forms (Table 3). Both resting spores and resting cells had higher unsaturation ratios than vegetative cells, and resting spores had the highest ratio in reference to $\mathrm{C}_{16}$ fatty acids, $\mathrm{C}_{18}$ fatty acids and all fatty acids combined.

Examining fatty acids in neutral and polar lipids separately, the majority ( 74 to $90 \%$ ) of neutral lipids were composed of $C_{14: 0}, C_{16: 0}$ and $C_{16: 1}$ fatty acids in all 3 life forms as found for the combined fatty acids (Table 4 ). Large accumulations of these fatty acids in neutral lipids were eminent in both resting spores and resting cells. Resting spores also accumulated larger amounts of these 3 fatty acids in polar lipids than vegetative cells. The amounts of $\mathrm{C}_{14}, \mathrm{C}_{16}$ and $\mathrm{C}_{18}$ fatty acids all deceased, but that of polyunsaturated $C_{20}$ fatty acid slightly increased in polar lipids of resting cells compared with vegetative cells.

These results indicated that resting spores accumulated large amounts of both neutral and polar lipids, mainly synthesizing $C_{14: 0}, C_{16: 0}$ and especially $C_{16: 1}$ fatty acids, while resting cells greatly accumulated neutral lipids, mainly composed of those 3 fatty acids, but reduced the contents of almost all fatty acids in polar lipids during the transition from vegetative cells. These 2 life form transitions were also shown to involve significant increases in unsaturated fatty acids.

\section{Carbohydrate components}

Carbohydrates were further separated into 3 fractions, methanol extraction, hot water extraction and residue, which were regarded as consisting of mono-f oligosaccharides, reserved polysaccharide and cell wall components, respectively (Handa 1969, Hama \& Handa 1987, 1992). The carbohydrate contents of each fraction of resting spores showed significant differences compared with the other life forms. Resting spores contained 7 times more mono-/oligosaccharides, 5 times more reserved polysaccharides and 2 times more cell wall components than vegetative and resting cells (Fig. 6). However, the proportion of each fraction in total carbohydrates did not differ much among the 3 life forms: about $20 \%$ mono-/oligosaccharides, about $60 \%$ reserved polysaccharides, and about $20 \%$ cell wall components, although the proportion of mono-/oligosaccharides was slightly more and that of cell wall components was slightly less in resting spores than in vegetative and resting cells.

Analyzing monosaccharide composition of total carbohydrates, resting spores showed significant differences compared with the other life forms. Carbohydrates of resting spores consisted mainly of glucose, which reached about $90 \%$ of the total carbohydrate and was 20 times more than in vegetative and resting cells (Table 5). Vegetative and resting cells contained

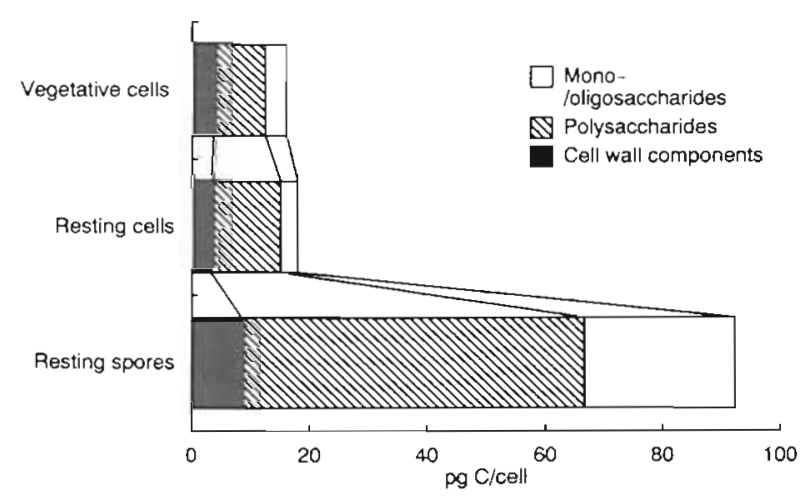

Fig. 6. Chaetoceros pseudocurvisetus. Carbohydrate contents of vegetative and resting cells and resting spores 
Table 5. Chaetoceros pseudocurvisetus. Monosaccharide composition (pg C cell- ${ }^{-1}$ ) of vegetative and resting cells and resting spores. Numbers in parentheses are percentages of total carbohydrates

\begin{tabular}{|lccr|}
\hline $\begin{array}{l}\text { Mono- } \\
\text { saccharide }\end{array}$ & $\begin{array}{c}\text { Vegetative } \\
\text { cells }\end{array}$ & $\begin{array}{c}\text { Resting } \\
\text { cells }\end{array}$ & \multicolumn{1}{c|}{$\begin{array}{c}\text { Resting } \\
\text { spores }\end{array}$} \\
\hline Rhamnose & $2.09(13.0)$ & $2.44(13.6)$ & $1.25(1.4)$ \\
Fucose & $0.93(5.8)$ & $1.42(7.9)$ & $0.76(0.8)$ \\
Ribose & $2.93(18.3)$ & $2.36(13.1)$ & $0.68(0.7)$ \\
Arabinose & $0.79(4.9)$ & $0.47(2.6)$ & $0.45(0.5)$ \\
Xylose & $1.58(9.9)$ & $2.80(15.6)$ & $0.86(0.9)$ \\
Mannose & $1.55(9.7)$ & $1.99(11.0)$ & $4.10(4.4)$ \\
Galactose & $2.39(14.9)$ & $2.96(16.4)$ & $2.00(2.2)$ \\
Glucose & $3.78(23.6)$ & $3.57(19.9)$ & $82.1(89.1)$ \\
\hline
\end{tabular}

similar amounts of 6 major monosaccharides: rhamnose, ribose, xylose, mannose, galactose and glucose which occupied about or more than $10 \%$ for each individual and nearly $90 \%$ of the total carbohydrate in vegetative and resting cells.

When examined for each component of carbohydrates, significant differences in the amount of monosaccharides were also found between resting spores and the other life forms (Table 6). Resting spores contained much larger amounts of glucose in each component than the other life forms. About $90 \%$ of mono-/oligosaccharides and reserved polysaccharides and $60 \%$ of cell wall components of resting spores were composed of glucose. Each carbohydrate component of resting cells was similar in monosaccharide content and composition to those of vegetative cells. However, it was noteworthy that ribose was most abundant in mono-/oligosaccharides of vegetative cells, while glucose was most abundant in those of resting cells and resting spores.

These results indicated that resting spores accumulated large amounts of glucose in the form of mono-/ oligosaccharides, cell wall components and mainly reserved polysaccharides (mostly glucan) which occupied a large part of accumulated carbon. On the other hand, resting cells almost maintained similar contents and compositions of monosaccharides in mono-/ oligosaccharides, polysaccharides and cell wall components as the vegetative cells.

\section{DISCUSSION}

The term 'resting cell' was first adopted for diatom cells that had no positive growth, had distinctive cytological characteristics such as compaction of organelles as observed by Lund (1954), and were found in lake sediments. The resting cells recovered when exposed to radiation (Lund 1954, Sicko-Goad et al. 1986). The

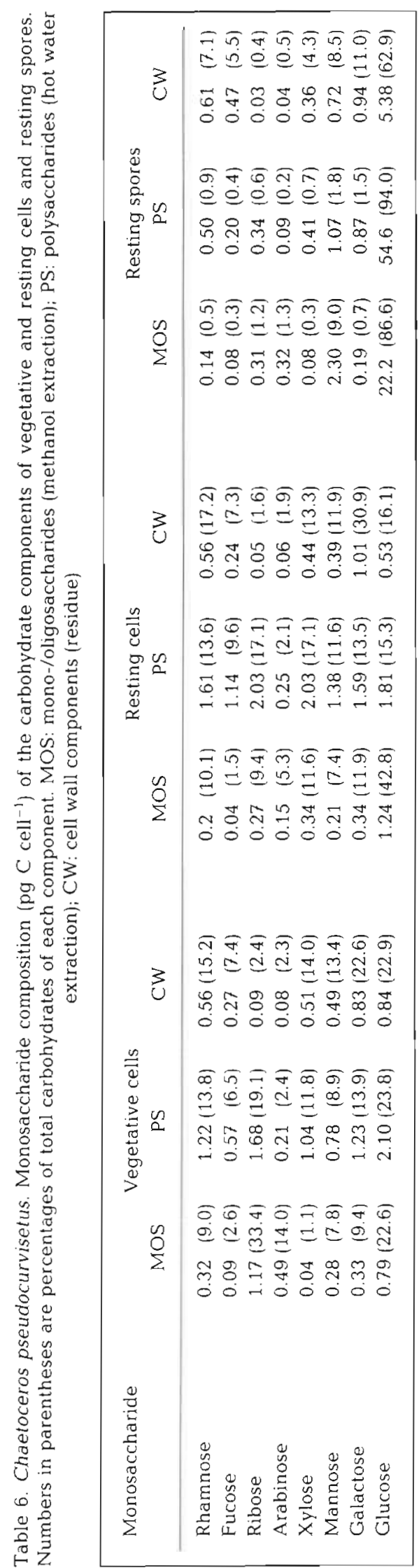


resting cells obtained in the present study had similar morphological characteristics to those mentioned above, and recovered to vegetative cells up to a certain time period when transferred to the environment suitable for vegetative growth (unpubl. results). It then became evident that a planktonic diatom population of Chaetoceros pseudocurvisetus produced 2 specialized life forms, resting spores and resting cells, depending upon differences in nutrient deficiency induced by nitrate as nitrogenous nutrient and silicic acid.

For planktonic algae to survive under conditions unfavorable for vegetative growth, such as nutrient deficiency, it is essential to maintain at least some metabolic processes until environmental conditions turn favorable. Dormant stages of a wide variety of organisms for survival under unfavorable growth conditions have been known to demonstrate reduced metabolic activity and accumulation of storage products (Sussman \& Douhit 1973).

Both resting spores and resting cells of Chaetoceros pseudocurvisetus exhibited low respiratory and photosynthetic activity (Table 1), although resting spores suppressed respiratory activity more than resting cells. Resting spores maintained slightly positive diel net photosynthesis while resting cells maintained a slightly negative rate. The observed reduction of respiratory activity of the resting spores is supported by the studies of 5 other diatoms (French \& Hargraves 1980). Resting cells of another diatom, Amphora coffaeformis formed in dark and cold conditions exhibit low respiratory activity relative to vegetative cells (Anderson 1976). Similar low respiratory activity was also shown in akinetes of a cyanobacterium and resting cysts of a dinoflagellate (Chauvat et al. 1982, Binder \& Anderson 1990).

The analysis of fatty acid composition revealed that resting spores and resting cells both accumulated larger amounts of neutral lipids than vegetative cells (Fig. 5). Neutral lipids can be regarded as stored material to be used for the maintenance of basic metabolic processes until conditions improve, at which point the remaining neutral lipids could be available as an energy and carbon source for rebuilding the photosynthetic apparatus and other metabolic systems (Roessler 1990). Cysts of a chlorophyte and a chrysophyte were also revealed to accumulate lipids (Berkaloff \& Kader 1975, Lichtlé \& Dubacq 1984). Ultrastructual examinations indicated that resting spores of Thalassiosira antarctica and resting cells of Amphora coffaeformis formed in darkness at a low temperature contain lipid droplets which were considered to be composed of neutral lipids (Anderson 1975, Doucette et al. 1984). Since resting cells contained similar amounts of organic carbon to vegetative cells (Table 2), the carbon source for the newly synthesized neutral lipids in this life form can be partially explained by degradation of polar lipids (Fig. 5). Such conversion from polar to neutral lipids during the transformation from vegetative to resting cells was also observed in the resting stages of some other algae (Berkaloff \& Kader 1975, Lichtle \& Dubacq 1984). Neutral lipids of resting spores and resting cells consisted mainly of saturated and monosaturated fatty acids, such as palmitoleic $\left(\mathrm{C}_{16: 1}\right)$, palmitic $\left(\mathrm{C}_{16: 0}\right)$ and myristic $\left(\mathrm{C}_{14: 0}\right)$ acids (Table 4$)$. Since saturated and monosaturated fatty acids provide more energy upon oxidation than polyunsaturated fatty acids, they possibly allow more efficient packaging of the storage lipids (Roessler 1990).

Since neutral lipids contain higher energy (ca 9 kcal $\mathrm{g}^{-1}$ ) than reserved polysaccharides $\left(4 \mathrm{kcal} \mathrm{g}^{-1}\right)$ and can be stored in more concentrated form, it can be considered to be more advantageous to accumulate neutral lipids as storage compounds (Lehninger 1975). However, resting spores of Chaetoceros pseudocurvisetus accumulated a large amount of carbohydrates which comprised the major part of accumulated carbon, whereas the resting cells kept a similar composition of carbohydrates to that of vegetative cells (Fig. 4). Furthermore, a large part (89\%) of carbohydrates accumulated in resting spores was glucose in monooligosaccharides and mainly glucan in polysaccharides (Tables 5 \& 6). Handa (1969) showed that glucose and ß-1-3 glucan were readily metabolized by dark respiration in the marine diatom Skeletonema costatum. Stored glucose and glucan in resting spores of $C$ pseudocurvisetus would be available as an energy source for maintenance under nutrient deficiency. In fact, storage of glucan under nitrogen-limited conditions is a common phenomenon which has been observed in several marine diatom species (Myklestad 1974) and also in the natural algal community in the nutrient-depleted 'aged' upwelling area (Hama 1988) where resting spore formation of C. pseudocurvisetus is likely to occur (Kuwata \& Takahashi 1990). Similar accumulation of carbohydrates also occurs in some other algal cysts, for example a blue green alga and a dinophyte (Sutherland et al. 1979, Binder \& Anderson 1990).

Nutrient stress can be considered as particularly influencing planktonic algal life. For algal cells with arrested vegetative growth under nutrient deficiency in the euphotic zone, excess energy captured by photosynthetic apparatus can cause lethal photochemical damages (Belay \& Fogg 1978). To avoid this photochemical damage, curtailment of inputted photochemical energy and/or utilization of this excess energy for energy-consuming processes could be important. Observed nearly zero net photosynthesis, achieved by suppressing both photosynthetic and respiratory capacities of resting spores and resting cells, accompa- 
nied by the reduction of organic nitrogen and chl a contents, could be considered effective to avoid this damage (Tables 1 \& 2). Furthermore, synthesis and unsaturation of fatty acids require photosynthetically produced ATP and NAD $(\mathrm{P}) \mathrm{H}$, and can be regarded as processes consuming excess photochemical energy. Accumulation of lipids and increased unsaturation of fatty acids of resting spores and resting cells of Chaetoceros pseudocurvisetus under nitrogen deficiency were considered to help protect against possible photochemical damage (Fig. 4, Table 3).

Based on the information mentioned above, it can be concluded that both resting spores and resting cells of Chaetoceros pseudocurvisetus can be regarded as adaptive dormant stages for the survival of this algal population under nutrient depletion. Considering that final cell yields and cellular content of organic nitrogen did not differ significantly between resting spores and resting cells (Figs. $2 \& 3$, Table 2), the following processes can be considered to occur in the formation of resting spores and resting cells of $C$. pseudocurvisetus. Encountering nitrogen depletion, the vegetative cells can continue to divide one more time while reducing cellular nitrogen contents to a minimum (Figs. $2 \& 3$ ). At this time, if these algal cells can utilize large amounts of silicic acid from the surrounding environment, they enter the process of forming resting spores and absorb large amounts of silica to produce new thickened cell walls (Figs, $1 B$ \& 2, Table 2; also Kuwata \& Takahashi 1990). If there is not enough silicic acid available in the environment, they initiate formation of resting cells, keeping vegetative-looking forms (Figs. 1C \& 3). Although Hargraves \& French (1983) have previously pointed out that the formation of resting spores costs one or more cell divisions in terms of final cell yield, it has become clear that acquisition of a large amount of silicate is the cost. The formation of resting spores involves greater suppression of respiratory activity and larger loading of storage products, leading to the profoundly dormant stage, while resting cell formation together with smaller changes in both metabolic activity and cellular component leads to a resting state which requires the consumption of small amounts of cellular carbon to survive.

Since resting spores of this alga and many other diatoms have heavily silicified frustules (Hargraves 1976), acquisition of a large amount of silica can be considered to be a general condition for resting spore formation of diatoms. Consequently, the formation of 2 different dormant cells, resting spores and resting cells, within the same population, as revealed in Chaetoceros pseudocurvisetus when confronted with nutrient depletion, can be regarded as a common response of spore-forming diatoms under natural limitation of available silicic acid. Considering revealed differences of ecophysiological characteristics between resting spores and resting cells, each life form is expected to exhibit different behaviors and plays a specific role in the maintenance of a spore-forming diatom population under various nutrient fluctuations in natural water.

Acknowledgements. We thank Dr M. Nishimura and Mr Y. Suzuki for technical advice, and Prof S. Katoh and Drs N. Satoh and J. Ishizaka for valuable suggestions. This work was supported by a Grant in aid of Cooperative Research (No. 63304002) from the Ministry of Education, Science and Culture of Japan.

\section{LITERATURE CITED}

Anderson, O. R. (1975). The ultrastructure and cytochemistry of resting cell formation in Amphora coffaeformis (Bacillariophyceae). J. Phycol. 11: 272-281

Anderson, O. R. (1976). Respiration and photosynthesis during resting cell formation in Amphora coffaeformis (Ag.) Kütz. Limnol. Oceanogr. 21: 452-456

Belay, A., Fogg, G. E. (1978). Photoinhibition of photosynthesis in Asterionella formosa (Bacillariophyceae). J. Phycol. 14: $341-347$

Berkaloff, C., Kader, J. C. (1975). Variations of the lipid composition during the formation of cysts in the green alga Protosiphon botryoides. Phytochemistry 14: 2353-2355

Binder, B. J., Anderson, D. M. (1990). Biochemical composition and metabolic activity of Scrippsiella trochoidea (Dinophyceae) resting cysts. J. Phycol. 26: 289-298

Chauvat, F., Corre, B., Herdman, M., Joset-Espardellier, F (1982). Energetic and metabolic requirements for the germination of akinetes of the cyanobacterium Nostoc PCC 7524. Arch. Microbiol. 133: 44-49

Cupp, E. E. (1943). Marine plankton diatoms of the west coast of North America. Bull. Scripps Instn Oceanogr. tech. Ser. 5: $1-238$

Davis, C. O., Hollibaugh, J. T., Seibert, D. L. R., Thomas, W. H., Harrison, P. J. (1980). Formation of resting spores by Leptocylindrus danicus (Bacillariophyceae) in a controlled experimental ecosystem. J. Phycol. 16: 296-302

Doucette, G. J., Burghardt, R. C., Fryxell, G. A. (1984). The genus Thalassiosira: protoplast ultrastructure of the bipolar diatom Thalassiosira antarctica. Can. J. Bot. 62: $1511-1522$

Doucette, G. J., Fryxell, G. A. (1983). Thalassiosira antarctica: vegetative and resting stage chemical composition of an ice-related marine diatom. Mar. Biol. 78: 1-6

Drebes, G. (1966). On the life cycle of the marine plankton diatom, Stephanophyxis palmeriana. Helgoländer wiss. Meeresunters. 13: 101-115

French, F. W.. Hargraves, P. E. (1980). Physiological characteristics of plankton diatom resting spores. Mar. Biol. Lett. 1: $185-195$

Garrison, D. L. (1981). Monterey Bay phytoplankton. II. Resting spore cycles in coastal diatom populations. J. Plankton Res. 3: $137-156$

Guillard, R. R. L., Ryther, J. H. (1962). Studies of marine planktonic djatoms. I. Cyclotella nana Hustedt and Detonula Confervacea (Cleve) Gran. Can. J. Microbiol. 8: $229-239$

Hama, J., Handa, N. (1992). Diel variation of water- 
extractable carbohydrate composition of natural phytoplankton populations in Kinu-ura Bay. J. exp. mar Biol. Ecol. 162: 159-176

Hama, T. (1988). ${ }^{13} \mathrm{C}-\mathrm{GC}-\mathrm{MS}$ analysis of photosynthetic products of the phytoplankton population in the regional upwelling area around the Izu Islands, Japan. Deep Sea Res. 35: 91-110

Hama, T., Handa, N. (1987). Pattern of organic matter production in natural phytoplankton population in a eutrophic lake. I. Intracellular products. Arch. Hydrobiol. 109: $107-120$

Handa, N. (1969). Carbohydrate metabolism in the marine diatom Skeletonema costatum. Mar. Biol. 4: 208-214

Handa, N., Yanagi, K. (1969). A detailed analysis of carbohydrates in marine particulate matter. Mar. Biol. 2: 228-235

Hargraves, P. E. (1976). Studies on marine plankton diatoms. II. Resting spore morphology. J. Phycol. 12: 118-128

Hargraves, P. E., French, F. W. (1983). Diatom resting spores: significance and strategies. In: Fryxell, G. A. (ed.) Survival strategies of the algae. Cambridge University Press, New York, p. 49-68

Holmes, R. W. (1966). Light microscope observations on cytological manifestations of nitrate, phosphate, and silicate deficiency in four marine diatoms. J. Phycal. 2: 136-140

Hoshaw, R. W., Rosowski, J. R. (1973). Isolation and purification: methods for microscopic algae. In: Stein, J. R. (ed.) Handbook of phycological methods: culture and growth measurements. Cambridge University Press, Cambridge, p. 53-68

Ishizaka, J., Kaichi, M., Takahashi, M. (1987). Resting spore formation of Leptocylindrus danicus (Bacillariophyceae) during short time scale upwelling and its significance as predicted by a simple model. Ecol. Res. 2: 229-242

Kuwata, A., Takahashi, M. (1990). Life-form population responses of a marine planktonic diatom, Chaetoceros pseudocurvisetus, to oligotrophication in regionally upwelled water. Mar. Biol. 107: 503-512

Lehninger, A. L. (1975). Biochemistry. Worth Publishers, Inc., New York

Lichtlé, C., Dubacq, J. P. (1984). Lipid modifications related to encystment and excystment of Cryptomonas rufescens Skuja (Cryptophyceae). J. Phycol. 20:8-12

Lund, J. W. G. (1954). The seasonal cycle of the plankton diatom, Melosira italica (Ehr.) Kütz. subsp. subarctica $\mathrm{O}$.

This article was presented by K. Furuya, Tsu, Japan
Müll. J. Ecol. 42: 151-179

Miyai, H., Matsuzaki, K., Ogawa, K., Sugihara, T (1988). A simple method for the estimation of phytoplankton biomass based on cell morphology. Bull. Plankton Soc. Japan 35: $121-126$

Myklestad, S. (1974). Production of carbohydrates by marine planktonic diatoms. I. Comparison of nine different species in culture. J. exp. mar Biol. Ecol. 15: 261-274

Paasche, E. (1980). Silicon content of five marine planktonic diatom species measured with a rapid filter method. Limnol. Oceanogr. 25: 474-480

Roessler, P. G. (1990). Environmental control of glycerolipid metabolism in microalgae: commercial implications and future research directions. J. Phycol. 26: 393-399

Sicko-Goad, L., Stoermer, E. F., Fahnenstiel, G. (1986). Rejuvenation of Melosira granulata (Bacillariophyceae) resting cells from the anoxic sediments of Douglas Lake, Michigan. I. Light microscopy and ${ }^{14} \mathrm{C}$ uptake. J. Phycol. 22 $22-28$

Strickland, J. D. H., Parsons, T. R. (1972). A practical handbook of seawater analysis. Bull. Fish. Res. Bd Can. 167: $1-311$

Sussman, A. S., Douhit, H. A. (1973). Dormancy in microbial spores. A. Rev. Plant Physiol. 24: 311-52

Sutherland, J. M., Herdman, M., Stewart, W. P. (1979). Akinetes of the cyanobacterium Nostoc PCC 7524: macromolecular composition, structure and control of differentiation. J. gen. Microbiol 115: 273-287

Suzuki, R., Ishimaru, T (1990). An improved method for the determination of phytoplankton chlorophyll using $\mathrm{N}, \mathrm{N}$ dimethylformamide. J oceanogr Soc Japan 46: 190-194

Takahashi, M., Ishizaka, J., Ishimaru, T., Atkinson, L. P., Lee, T N., Yamaguchi, Y., Fujita, Y., Ichimura, S. (1986). Temporal change in nutrient conditions and phytoplankton biomass in short time scale local upwelling around the Izu Peninsula, Japan. J. Plankton Res. 8: 1039-1049

Takano, H. (1990). Chaetoceros pseudocurvisetum Mangin. In: Fukuyo, Y., Takano, H., Chihara, M., Matsuoka, K. (eds.) Red tide organisms in Japan - an illustrated taxonomic guide. Uchida Rokakuho, Tokyo, p. 290-291

Utermöhl, H. (1958). Zur Vervollkommnung der quantitativen Phytoplankton-Methodik. Mitt. int. Verein. theor. angew. Limnol. 9: 1-38

Manuscript first received: June 7, 1993

Revised version accepted: September 6, 1993 